\title{
CRITERIA FOR THE ADMISSION OF OLDER PATIENTS IN THE INTENSIVE CARE UNIT: CHRONOLOGICAL AGE CANNOT BE THE UNIQUE FACTOR
}

\section{Critérios de internação em unidade de terapia intensiva para idosos: idade cronológica não pode ser fator decisório isolado}

The intensive care units aim to provide care to critically ill and at-risk patients, who are likely to survive and recover, requiring uninterrupted medical assistance, in addition to specialized technological and human resources.

Among the factors on which admissions to the intensive care unit (ICU) should be based, are the diagnosis and the patient's need, and the potential benefit from therapeutic interventions and prognosis.

The Resolution of the Federal Council of Medicine (CFM) No. 2.156 / 2016 establishes the ICU admission and discharge criteria, and among the priorities listed for admission, are: ${ }^{1}$

- Patients in need of life support interventions, with high probability of recovery and no limitation of therapeutic support;

- Patients who need intensive monitoring, due to the high risk of need for immediate intervention, and without any limitation of therapeutic support.

Clinical evaluation, including medical and social history, functional capacity before admission, and advance directives, is fundamental for decision-making regarding referral of the older adult to the ICU. ${ }^{2}$ The decision must be shared with the older patient and the family, respecting their preferences.

Chronological age alone is not an acceptable predictor of critical illness regarding mortality and quality of life of older adults in the ICU. ${ }^{3}$ Functional capacity before admission has been shown to have an influence on mortality. Healthy and well-functioning older adults may have even better prognosis than younger patients.

The Acute Physiologic and Chronic Health Evaluation (APACHE) scores, the Simplified Acute Physiology Score (SAPS), the mortality prediction model (MPM0), and the Sequential (sepsis-related) Organ Failure Assessment (SOFA) are validated to predict outcomes (including mortality) of ICU patient populations. They are not useful for ICU referral. ${ }^{5}$
It is important to emphasize that, in cases of incurable and terminal diseases, the physician must offer the available palliative care measures, without undertaking useless or obstinate diagnostic or therapeutic actions, respecting the will of the patient or his legal representative. ${ }^{1}$

Communication between the intensive care team, the older adult, and the family is essential in formulating the treatment plan, respecting the wishes of the older person.

Last statement update

Issued on March 26, 2020.

Special Commission COVID-19, Brazilian Society of Geriatrics and Gerontology (Sociedade Brasileira de Geriatria e Gerontologia - SBGG)

\section{Maisa Carla Kairalla}

Coordinator of the Special Commission COVID-19 of the SBGG

\section{Paulo José Fortes Villas Boas}

Member of the Special Commission COVID-19

of the SBGG

Daniel Christiano de Albuquerque Gomes Member of the Special Commission COVID-19 of the SBGG

\section{Jarbas de Sá Roriz Filho Member of the Special Commission COVID-19 of the SBGG}

\section{Renato Gorga Bandeira de Mello} Scientific Director of the SBGG 


\section{REFERENCES}

1. Conselho Federal de Medicina. Resolução CFM no 2.156/2016. Estabelece os critérios de admissão e alta em unidade de terapia intensiva [Internet]. CFM; 2016 [Accessed in 28 mar. 2020]. Available from: https://sistemas.cfm.org.br/normas/visualizar/resolucoes/ BR/2016/2156

2. Vallet H, Riou B, Boddaert J. [Elderly patients and intensive care: Systematic review and geriatrician's point of view]. Rev Med Interne. 2017;38(11):760-5. https://doi.org/10.1016/j. revmed.2017.01.014

3. Cintra MTG, Belém D, Moraes EN, Botoni FA, Bicalho MAC. The impact of intensive care admission criteria on elderly mortality. Rev Assoc
Med Bras (1992). 2019;65(7):1015-20. https://doi.org/10.1590/18069282.65.7.1015

4. Villa P, Pintado M-C, Luján J, González-García N, Trascasa M, Molina $\mathrm{R}$, et al. Functional Status and Quality of Life in Elderly Intensive Care Unit Survivors. J Am Geriatr Soc. 2016;64(3):536-42. https:// doi.org/10.1111/jgs.14031

5. Kelley M. Predictive scoring systems in the intensive care unit. UpToDate [Internet]. 2020 [Accessed in 28 mar. 2020]. Available from: https://www. uptodate.com/contents/predictive-scoring-systems-in-the-intensive-careunit?search=Illness\%20Severity\%20Scores\%20apache\&source=search result\&selectedTitle=1 150\&usage_type=default\&display_rank=1 